Revista de la red interuniversitaria de estudios sobre las literaturas rioplatenses contemporáneas en Francia

7 | 2012

Arqueologías

\title{
Cosas de Edgardo Dobry
}

Julio Premat

\section{OpenEdition}

\section{Journals}

\section{Edición electrónica}

URL: http://journals.openedition.org/lirico/710

DOI: 10.4000/lirico.710

ISSN: 2262-8339

Editor

Réseau interuniversitaire d'étude des littératures contemporaines du Río de la Plata

\section{Referencia electrónica}

Julio Premat, "Cosas de Edgardo Dobry », Cuadernos LIRICO [En línea], 7 | 2012, Puesto en línea el 01

julio 2012, consultado el 19 abril 2019. URL : http://journals.openedition.org/lirico/710 ; DOI :

$10.4000 /$ lirico. 710

Este documento fue generado automáticamente el 19 abril 2019.

\section{(c) (i) (9)}

Cuadernos LIRICO está distribuido bajo una Licencia Creative Commons Atribución-NoComercialSinDerivar 4.0 Internacional. 


\title{
Cosas de Edgardo Dobry
}

\author{
Julio Premat
}

1 Sobre un fondo color papel madera, como el de las bolsas de panadería o de ferretería de otros tiempos, una palabra: Cosas dice el título, abajo del apellido DOBRY, con mismo número de letras y el mismo largo, como un reflejo. ¿Y qué dice el título cuando dice "cosas"? ¿De qué cosas se trata, de qué cosas trata? ¿En ese sobre, en ese paquete cuidadosamente envuelto, qué hay? ¿Qué cosas en hay en libro de Dobry, que cosas hay en el nombre de poeta "Dobry" ?

La respuesta más simple, retomando la lección bien aprendida sobre debates y corrientes de la poesía argentina de los últimos veinticinco años: cosas y no poemas, objetos materiales, cosas que están, objetivismo, materialismo. Y enumero: óxido, puertas, picaportes, azufre, carbón, plástico, nervaduras, llaves, aspirinas, gabanes, boletos, caramelos de mentol, poleas, tubos, aviones, pneumáticos. Esas son las cosas empíricas, no los fenómenos, que se nombran detrás de esa tapa.

Pero también podemos decir que las cosas de las que se trata son los textos. Un libro hecho de 87 cosas. Poema/cosa: también objetivismo. Y en ese caso, evocar una característica muy visible y espectacular : la brevedad lacónica de un poemario, a veces con tonos de aforismo o de epigrama, pero que la mayor parte de las veces da la impresión de estar escrito por sustracción, como por concentración de materia hacia una forma escueta y densa el mismo tiempo. Es decir, por condensación, retomando la expresión del mismo Dobry sobre Pizarnik en Orfeo en el quiosco de diarios, una condensación que da la impresión (cito p. 164) "que cada línea está impulsada por la fuerza de todo lo que no nombra, de todo lo que debió quedar afuera para que el verso saliera impulsado hacia nosotros con un resorte comprimido y soltado de golpe." La poesía como condensación o cristalización, en el sentido químico, de algo más amplio y más aéreo, podría decirse. Sustracciones, concentración, resto material de discursos anteriores que dejarían huellas, como el anacoluto y el hipérbaton, sistemáticos en los textos. Un desorden surgido de una reducción, de una desaparición. En lo que queda, en la alteración sintáctica, a veces con resabios barrocos tradicionales, surge la consistencia. Concentración y alteración son las que le dan, pareciera entonces, materialidad de objeto, de cosa, a lo que leemos. 
$4 \quad$ ¿Y de qué cosas hablan esas cosas? La poesía aparece, en varios textos, como canto de lo concreto, la poesía dentro, y a partir de eso que nos rodea, firme, en el mundo. "Bajo la maceta/las hormigas rompen/las crestas de la llave" (9). Epifanía de lo que es y de lo que probamos. Epifanía de eso, del instante, hecho palabra, como en la brusca musicalidad que se abre al final de un verso, de pronto : "el borracho barco" (37). U otro instante, en donde el objeto se vuelve explicación y expresión soleada, la cosa se vuelve lenguaje en contra de lo sombrío. Cito :

19

En la cocina sombría me brindo

la expresión de una naranja :

sol explicado al paladar.

5 Esas cosas, fatalmente, pasan : pasan de estar a estuvieron. La cosa, lo que se dice, pasa, muchas veces, por cosas que pasaron, por una materialidad evocada. Los sonidos y las figuras se mezclan con el sueño y, sutilmente, con el recuerdo, con lo que quizás ya no está (como puede leerse, en clave, en este ejemplo) :

29

Corneta hiere el sueño de la siesta,

el churrero pedalea tras la sombra

de un plátano subida al trolebús.

6 Mi lectura es quizás autocentrada en una infancia porteña (siempre hubo, me dicen, trolebús en Rosario), pero desde mi recuerdo, leo trolebús desaparecidos en los sesenta y marcados por una sombra fugaz, la siesta de otrora cortada por un churro infantil, la imagen rápida de la bicicleta atrás de algo que pasó y que de nuevo está pasando en el duermevela de un despertar lejano.

7 Porque las cosas son huellas de otras cosas. Pero lo que queda, las huellas, son a su vez huellas de algo leído, el eco de algunas imágenes y metáforas que vienen de otro lugar, esas cosas escritas por Girondo en Veinte poemas para ser leídos en el tranvía, por ejemplo, como la sombra que "se separa de mí, y de pronto, se arroja entre las ruedas de un tranvía" ("Apunte callejero") mientras que aquí la sombra se sube a un trolebús en donde quién sabe quién lee poemas que Dobry todavía no escribió. Huellas de otros también en la corneta del churrero, en donde suenan resabios de las cosas de Vallejo, las de Trilce, esa "serpentínica u del bizcochero/enjirafada al tímpano" (poema XXXII). Y otra vez de Vallejo, cosas de "Confianza en el anteojo, no en el ojo", con su estribillo "y en ti sólo, en ti sólo, en ti sólo", lo que suena en Dobry como un "Mi yo de mi yo de mi yo" (23). Y más cosas, las de un yo de poeta, el de Darío de Canciones de vida y esperanza, que en Dobry ya no está :

65

Ahora bien, aquel que ayer nomás decía hoy no está, vino temprano

a otros asuntos, ya se fue.

O el bolero "Vete de mí" que cambia de estética cuando cambia de contexto :

34

El verso aquel que no sabemos

recordar : casa, tubos, rumor de otoño.

9 En todo caso vemos cómo, de una cosa a la otra, las cosas de Dobry pierden materialidad. Ya no sólo lo que está o estuvo, sino lo que sucede, lo que pasa o pasó, lo que sucedió ayer o en un vago tiempo de la memoria subjetiva. Inicio del poema 52 : "Miraban la entrega de 
los Oscar,/padre se acordó : una vez/había estado en Los Angeles..." Les choses de la vie, como decía el título de una vieja película francesa con Michel Piccoli y Romy Schneider. 0 más bien, la cosa es un recuerdo objetivado, un recuerdo hecho espacio, materia, escena, como este arenque y este pan negro :

56

Pésimo me cae esta tarde

el arenque plateado que apretaba

bisabuelo sobre pan muy negro

una mañana de diciembre en Chisinau.

$10 \mathrm{Y}$ como quien no quiere la cosa, al final del libro un texto pareciera intentar definir de qué cosas se trata, un poema en el que vemos a las cosas arrastradas por una ley de gravedad hacia un centro incandescente y destructivo :

79

Gravedad de las cosas reclamadas

por el centro incandescente de la tierra.

Están caídas en su letra,

son figuras sólo nuestras.

11 Las cosas caen pero quedan, se salvan, perduran un instante, en la letra. Las cosas son figuras nuestras para olvidar lo inolvidable, para disolver eso que la lágrima no sabe decir (poema 24 : "La lágrima no disuelve/lo que no sabe decir"). Hay un lirismo apretado en Cosas, un lirismo que no alcanza a estallar o que apunta a algo más que al simple estallido. Un lirismo consciente de que es difícil evitar que "en la foto aparezca/la sombra del fotógrafo" (leído en el poema 86). Un lirismo que sabe que, aunque haya una madre muerta recorriendo corredores de noche y llamando por teléfono en subjuntivo, aunque haya una memoria de antepasados de diáspora, aunque haya tiempo y exilio, siempre de la cosa, de una cosa, pasamos a la otra, a otra pérdida que ya no es nombrable.

La cosa es la chose del psicoanálisis, es la cosa en sí, die Ding de la filosofía, es el resto indefinible que permanece después de decir la pérdida y el duelo (aunque pérdida y duelo sean, después de todo, lo más constante en el libro), lo que va más allá de las cosas, más allá del objeto deseado y de la nostalgia. 0 sea : después de decir la pérdida y el duelo, después de dibujar un mapa material de nostalgia, queda todavía algo, eso, una cosa, frontera indecible, que justifica el decir que no dice de la literatura.

\section{BIBLIOGRAFÍA}

Edgardo Dobry, Cosas, Barcelona : Lumen 2008.

\section{AUTOR}

JULIO PREMAT

Universidad Paris 8 Vincennes - Saint-Denis 